\title{
Monetary Policy, Debt Maturity and Cash Holdings
}

\author{
Hujie \\ Department of Finance, Nanjing University of Finance and Economics, Nanjing, China \\ Email: hj10112002@163.com
}

Keywords: debt maturity structure; cash holding; monetary policy

\begin{abstract}
This paper combines debt maturity, monetary policy and cash holdings into the same analytical framework. Taking 835 A-share non-financial listed companies in Shenzhen and Shanghai as samples, we empirically analyzed through the simultaneous equation model and found that: company cash holding's possibility and debt period are determined endogenously. The shorter the company's debt maturity, the higher the refinancing risk, the more cash holdings; when the monetary policy is tightened, the listed company will increase cash holdings with caution. In the period of tight monetary policy, the cash holdings of listed companies with short debt maturities and high refinancing risks have increased more. Finally, further research in this paper shows that compared with state-owned enterprises, the cash holdings of non-state-owned enterprises are more affected by the debt maturity structure and monetary policy.
\end{abstract}

\section{Introduction}

From the classic literature at home and abroad, the company's motives for holding cash can be classified into three types: trading motives, cautious motives and agency motives. The motive of the transaction is that the company holds cash in order to avoid the transaction cost of converting non-cash assets into cash. The prudent motivation is that the company adjusts the cash holdings according to future investment opportunities and financing constraints. The impact of agency conflicts between managers and shareholders is received, as managers have incentives to hold large amounts of cash for personal gain. Looking at the current theory of cash holdings, there is little literature on whether a company's cash holdings are affected by the debt maturity structure.

This paper incorporates the debt maturity structure, monetary policy and cash holdings into the same analytical framework. Possible contributions are: 1. Incremental contributions to the debt maturity structure theory. Most of the existing researches analyze the impact of debt maturity structure from the perspectives of agency cost, executive compensation, and investment efficiency. This paper analyzes the economic consequences of debt maturity structure from the perspective of cash holding. 2 . Further enriching the literature on cash holdings. Most of the existing researches on the factors affecting cash holdings are based on financial characteristics, corporate governance and other factors. This paper starts from the debt maturity structure, monetary policy and other factors, and finds that the debt maturity structure and monetary policy also have significant influences on cash holdings.. Finally, the paper also analyzes the impact of monetary policy tightening on the company's cash holdings, and further enriches the literature on macroeconomic policies and micro-enterprise activities.

\section{Theoretical analysis and research hypothesis}

\subsection{Analysis of the mechanism of debt holdings affecting cash holdings}

There is uncertainty in the company's operating cash flow. When the company's external financing is limited, holding cash can provide sufficient strategic reserves to achieve important decisions such as continuous and stable capital investment. Available evidence suggests that stocking more cash helps strengthen the company's financial flexibility and meet the funding needs of the company's growth investment opportunities (Denis, 2010). Companies with strong financial flexibility can not only 
capture profitable investment opportunities, but also avoid financial distress to create value for the company (Duchin et al, 2010). When the company refinances, due to imperfections in the capital market, the cost of financing may rise, or even fail to finance, and the company's operations will be in trouble. "Cautious Motivation" believes that holding cash in the company can prevent possible risk shocks, which will be more intense when external financing costs are higher. Qiu \& Wan (2015) found that adequate cash holdings helped the company compete in technology and innovation, and technology spillovers were significantly positively correlated with cash holdings. Therefore, when the company faces fluctuating cash flow, it can use precautionary cash holdings to buffer the debt repayment risk and ensure the company's subsequent investment capacity.

When the company conducts loan financing, the lender will issue loans according to factors such as the company's credit status and size (Faulkender \& Petersen (2006)), so the lender can usually decide the terms of the loan, such as the loan term (Roberts \& Sufi (2009)). As a result, when the company finds that it can only enjoy preferential interest rates when making short-term loans, the company will increase its cash holdings to reduce the risk of refinancing. Large companies have more choices when making loans, such as finding bonds in the bond market for financing or negotiating with banks to negotiate loan terms. When these companies decide on debt maturity and cash holdings, they weigh the pros and cons of short-term debt and the risk of refinancing, while deciding on cash holdings to reduce the risk of refinancing.

However, as the company's cash holdings increase, the agency problem will reduce the contribution of over-holding to the prevention of corporate refinancing risks. Zhang Huili et al. (2012) found that when the company's cash holdings exceeded a certain level in China, serious agency problems would arise. As a corporate external governance mechanism, short-term debt will make management more frequently monitored by capital market participants. Compared with companies with longer debt maturities, the interests of the management of companies with short debt maturities and the interests of shareholders are more convergence. Therefore, short-term debt can alleviate the agency costs caused by excess cash holdings. Moreover, in China, bank loans are the main channel for listed companies to finance. Short-term debt will enable creditors such as banks to obtain more information about listed companies. Bank supervision should help to further reduce management's agency costs.

In summary, to study the impact of debt maturity and refinancing risk on the company's cash, it is necessary to take into account the possibility of cash holdings and the debt maturity is endogenously determined. If the lender provides a short-term loan to the company, the company may decide to hold more cash to mitigate the risk of refinancing. However, if the company holds too much cash, the short-term debt can enhance the supervisory role of the creditor, and the lender will have a tendency to provide short-term loans. Therefore, in the empirical study we use the simultaneous equation model, assuming that the cash holdings and the debt maturity structure are jointly determined.

Based on the above analysis, this paper proposes research hypothesis 1:

H1: The shorter the company's debt maturity, the higher the refinancing risk, the more cash holdings.

\subsection{Monetary policy and cash holding}

Monetary policy affects the real economy mainly through credit channels and currency channels (such as interest rates, exchange rates, and asset prices). The theory of monetary policy credit transmission mechanism believes that monetary policy can affect the real economy by regulating the bank's loans to enterprises. In China, the empirical research results of most scholars show that the credit channel is the main channel for the transmission of monetary policy. Rao Pingui and Jiang Guohua (2013) have shown that the micro-mechanism of credit policy in monetary policy exists in China. Therefore, monetary policy will have an important impact on market capital supply, which in turn will affect the company's cash holding decisions. Xiao Ming et al. (2013) found that monetary policy in China has a significant positive impact on the cash holdings of listed companies, while the impact of economic cycles and fiscal policies on cash holdings is negative and significant, and cash holdings of non-state-owned companies is more susceptible to macroeconomic changes. Cai et al. 
(2015) found that monetary policy significantly affects corporate cash holdings, and that listed companies increase their cash holdings when monetary policy tightens. In summary, this paper proposes research hypothesis 2 :

$\mathrm{H} 2$ : When monetary policy tightens, listed companies have higher levels of cash holdings.

Further, is the impact of refinancing risk on the company's cash holdings the same under monetary policy tightening and easing? As mentioned earlier, the credit channel is the main transmission channel of China's monetary policy, and bank credit has a procyclicality, which makes the influence of monetary policy on different enterprises asymmetrical when transmitted through credit channels. When monetary policy is loose, the amount of money in the financial market is large, and the capital needs of enterprises are easily met. At this point, the impact of refinancing risk on the financing of listed companies may not be too obvious. When monetary policy tightens, the supply of funds in the financial market will decrease, the phenomenon of credit rationing will become more serious, and banks will have more space to choose enterprises. In this selection process, the default of the debt contract will be the most important criterion, and the debt maturity structure will have a greater impact on corporate behavior than the easing period during the monetary policy tightening period. When the company's short-term debt level is high, the company must raise funds to repay the debts due. The source of funds for an enterprise may have two aspects: its own accumulation of funds, borrowing new debts and repaying old debts. When monetary policy tightens, the difficulty of external financing of enterprises increases. Therefore, the uncertainty of the external economic environment will force enterprises with high default risk to hold more cash to prevent liquidity shocks. Based on this, this paper proposes research hypothesis 3:

H3: During the monetary policy tightening period, the cash holdings of listed companies with short debt maturities and high refinancing risks increased more.

\section{Research design}

\subsection{Samples and data sources}

This paper selects A-share non-financial listed companies from 2001 to 2015 in Shenzhen and Shanghai, and screens the sample companies according to the following conditions: (1) not ST or PT during the sample period; (2) sample companies do not have the issuance of B shares (3) excludes companies with incomplete data. After the above treatment, the annual observations of 12,525 parallel panel data of 835 listed companies from 2001 to 2015 were obtained, involving 12 industry categories except the financial industry. In order to reduce the impact of outliers on the empirical results, we performed a winsorize treatment of the $1 \%$ and $99 \%$ extreme values of all continuous variables. The financial data comes from CCER, CSMAR and WIND, and the data is compared and filled.

\subsection{Definition of main variables}

This paper examines monetary policy from the perspective of monetary policy tightening and easing, so we must determine the monetary policy tightening year. Referring to the existing literature , this paper is based on the central bank's adjustment of deposit reserve, combined with the central bank's adjustment of deposit and loan interest rates to define the dummy variable (MP) of the monetary policy tightening stage. At the beginning of this century, China was in a state of deflation. In order to control deflation, China has implemented a loose monetary policy until 2004. According to public data, the central bank began to adjust the deposit reserve ratio in 2004, adjusting the deposit reserve ratio from $7 \%$ to $7.5 \%$. In 2006 , the central bank raised the deposit reserve ratio three times and eventually raised the deposit reserve ratio from $7 \%$ to $9 \%$. In 2007 , the central bank raised the deposit reserve ratio several times and eventually raised the deposit reserve ratio from $9 \%$ to $14.50 \%$. In 2008 , the US financial crisis spread. In order to alleviate the impact of the financial crisis on the real economy, the central bank repeatedly adjusted the deposit reserve ratio, implemented a moderately loose monetary policy, and removed the hard constraints on financial institutions' credit planning. 
From January 2010 to June 2011, the deposit reserve ratio was raised several times, eventually reaching $21.5 \%$. The adjustment of the benchmark interest rate for medium and long-term loans in the first to third years is similar. In 2004, the PBOC raised the loan interest rate to $5.76 \%$. In 2006, the benchmark interest rate for the loan was raised twice to $6.30 \%$. In 2007 , the benchmark interest rate for the loan was raised five times to $7.56 \%$. In 2008, the benchmark interest rate for loans was lowered five times to $5.40 \%$. From 2010 to 2011 , the benchmark interest rate for loans was raised four times to $6.65 \%$. In 2012, the loan interest rate was lowered to $6.15 \%$ twice. In 2014, it was lowered to $6.00 \%$. In 2015, it was lowered to 5\%. Based on the above analysis, we define 2004, 2006, 2007, 2010 and 2011 as the monetary policy tightening year.

Referring to the existing literature, this paper defines cash holdings as follows: cash and cash equivalents/total assets. In the robustness test, this article uses "cash and cash equivalents/(total assets - cash and cash equivalents)" to measure cash holdings. This article uses "long-term debt (more than one year)/total debt" to measure the debt maturity structure (Ld). The longer the debt maturity, the lower the default risk. In the robustness test, this paper uses "long-term borrowing (more than one year)/(long-term borrowing + short-term borrowing) to measure the debt maturity structure. (The definition of each variable is shown in Table 1 and Table2)

$$
\begin{aligned}
& \text { Cashhodings }_{i, t}=\gamma_{0}+\gamma_{1} \text { Ld }_{i, t}+\gamma_{2} M P+\gamma_{3} \text { MP }^{*} \text { Ld }_{i, t}+\gamma_{4} \text { Cashflow }_{i, t}+\gamma_{5} \text { TobinQ }_{i, t}+\gamma_{6} \text { Nwc }_{i, t} \\
& +\gamma_{7} \text { Size }_{i, t}+\gamma_{8} \text { Lev }_{i, t}+\gamma_{9} \text { Capex }_{i, t}+\gamma_{10} \text { Dividend }_{i, t}+\gamma_{11} \text { First }_{i, t}+\sum \text { Industry }+\varepsilon_{i, t} \\
& \text { Ld }_{i, t}=\beta_{0}+\beta_{1} \text { Cashholdings }_{i, t}+\beta_{2} \text { Cashflow }_{i, t}+\beta_{3} \text { Tobinq }_{i, t}+\beta_{4} \text { Roe }_{i, t}+\beta_{5} \text { Size }_{i, t} \\
& +\beta_{6} \text { Lev }_{i, t}+\beta_{7} \text { Am }_{i, t}+\beta_{8} \text { Taxrate }_{i, t}+\beta_{9} \text { First }_{i, t}+\sum \text { Industry }+\sum \text { Year }+\varepsilon_{i, t}
\end{aligned}
$$

Equation (1) is the cash holding equation, and we refer to the study by Opler et al. (1999) to set equation (1). According to the assumptions in this paper, we are concerned with the estimated coefficient of the $L d_{i, t}$ variable. If the estimate of $\gamma_{1}$ is significantly negative, it means that the higher the risk of refinancing, the higher the cash holdings of listed companies. we add the interaction term between the debt maturity structure (Ld) variable and the monetary policy (MP) to analyze the monetary policy tightening and expansion phase, and whether the default risk has different effects on cash holdings. In the estimation method, we establish equation (1) and equation (2) to establish a simultaneous equation model, and use two-stage least squares to estimate equation (1). To avoid the effects of collinearity, we did not add an annual dummy variable in the regression. Based on the assumptions in this paper, we expect the estimated coefficient of $\gamma_{3}$ to be significantly negative, that is to say, during the period of monetary policy tightening, listed companies with high default risk have more cash holdings.

Equation (2) is the debt term structure equation, the dependent variable is the debt maturity structure (Ld), and the cash holdings are the endogenous control variables determined jointly with the dependent variable. Based on the existing literature, we choose the following variables as control variables: Cash Flow, TobinQ, Return on Rot, Size of Company, Asset-Liability Ratio (Lev); Asset Term (Am) is equal to fixed Assets divided by total assets; the actual tax rate (Taxrate) is measured by dividing the income tax expense by the pre-tax accounting profit.

\section{Empirical results and analysis}

\subsection{Descriptive statistics of main variables}

As can be seen from Table 1, the average value of the sample company's cash holding ratio is $14.2 \%$, and the values of the 10th, $25 \mathrm{th}$, median, $75 \mathrm{th}$, and 90 th points are $3 \%, 6.5 \%$, and $11.4 \%$, respectively. $18.8 \%$ and $28.7 \%$, which indicates that the cash holding levels of different companies vary widely. The long-term debt accounted for $14.7 \%$ of the total debt, and the 10-, 25-, median, 75- and 90-point values were $0,0.4 \%, 7.7 \%, 23.5 \%$, and $41 \%$, respectively. It indicates that the level of debt maturity of different companies is quite different. 
Table1 Descriptive statistics of major variables

\begin{tabular}{|l|l|l|l|l|l|l|l|l|}
\hline Variable & Obs & Mean & Std & P10 & P25 & Median & P75 & P90 \\
\hline Cashholdings & 11690 & 0.142 & 0.138 & 0.030 & 0.065 & 0.114 & 0.188 & 0.287 \\
\hline Ld & 11690 & 0.147 & 0.178 & 0.000 & 0.004 & 0.077 & 0.235 & 0.410 \\
\hline Cashflow & 11690 & 0.047 & 0.089 & -0.044 & 0.005 & 0.047 & 0.091 & 0.143 \\
\hline TobinQ & 11690 & 1.549 & 0.948 & 0.877 & 1.018 & 1.260 & 1.749 & 2.596 \\
\hline Nwc & 11690 & -0.038 & 0.250 & -0.282 & -0.158 & -0.032 & 0.091 & 0.222 \\
\hline Roe & 11690 & 0.053 & 0.145 & 0.000 & 0.022 & 0.062 & 0.109 & 0.173 \\
\hline Size & 11690 & 21.715 & 1.204 & 20.320 & 20.875 & 21.602 & 22.426 & 23.340 \\
\hline Lev & 11690 & 0.517 & 0.253 & 0.249 & 0.375 & 0.515 & 0.645 & 0.748 \\
\hline Capex & 11690 & 0.034 & 0.048 & 0.000 & 0.003 & 0.016 & 0.047 & 0.092 \\
\hline First & 11690 & 0.385 & 0.164 & 0.189 & 0.254 & 0.361 & 0.510 & 0.621 \\
\hline Am & 11690 & 0.270 & 0.184 & 0.044 & 0.127 & 0.241 & 0.388 & 0.532 \\
\hline Taxrate & 11690 & 0.142 & 0.929 & 0.000 & 0.061 & 0.140 & 0.216 & 0.295 \\
\hline
\end{tabular}

Cashholdings is (cash and cash equivalents)/total assets, Ld is long-term debt (more than one year)/total debt, Nwc is net operating activity cash flow/total assets of the company, TobinQ is market value of total assets / book value of total assets, Roe is net profit / shareholder equity balance, Size is natural logarithm of total assets, Lev is total liabilities / total assets, Capex is capital expenditure / total assets, First is the shareholding ratio of the largest shareholder, Am is fixed assets / total assets, Taxraterate is income tax expense / pre-tax accounting profit.

\subsection{Empirical results}

We use the two-stage least squares method (2SLS) to estimate the simultaneous equations of equation (1) and equation (2). The regression results of equation (1) are shown in Table 2 (limited to space, no report equation (2) Return results).

The regression results in column (1) of Table 2 show that, firstly, the estimated coefficient of the debt maturity (Ld) variable is significantly negative, indicating that the listed company has a lower debt holding period, which means that the shorter the company's debt maturity, the refinancing risk, the higher the cash holding. This result is consistent with our expectation that the hypothesis H1 in this paper is supported by empirical evidence. Secondly, the estimation coefficient of the annual dummy variable (MP) of the monetary policy tightening is significantly positive, indicating that the company increased the cash holding level due to the cautious opportunity during the monetary policy tightening. The research hypothesis of this paper is verified by $\mathrm{H} 2$. Thirdly, the important variable we are concerned is the estimated coefficient of the interaction term between monetary policy and debt maturity $(\mathrm{MP} * \mathrm{Ld})$ which is significantly negative, indicating that during the period of monetary policy tightening, compared with listed companies with long debt maturities, the risk of refinancing of the listed companies with short debt maturities is high, so the cash holdings increase more, hypothesis $\mathrm{H} 3$ is verified.

From Table 2 we can see the regression results of the control variables: the estimated coefficients of operating cash flow (Cashflow) and dividend payment (Dividend) are significantly positive, net working capital ratio ( $\mathrm{Nwc}$ ), asset-liability ratio (Lev) and capital expenditure ( The estimated coefficient of Capex) is significantly negative. This suggests that companies that pay dividends and companies that operate more cash flow need to hold more cash. The more working capital, the higher the financial leverage and the more capital expenditures, the less cash they hold. The regression results of the control variables are basically consistent with the findings of Opler et al (1999) and Cai Weixing (2015). In the debt maturity structure equation, the estimated coefficient of cash holdings (Cashholdings) is significantly negative, indicating that short-term debt can enhance the supervisory role of creditors, and lenders have a tendency to provide short-term loans.

Table 2 Regression results of debt maturity, monetary policy and cash holdings

\begin{tabular}{|c|c|c|c|}
\hline \multirow{2}{*}{} & \multicolumn{3}{|c|}{ Cashholdings } \\
\cline { 2 - 4 } & $(1)$ & $(2)$ & $(3)$ \\
& Full sample & State-owned sample & Non-state sample \\
\hline Intercept & $-0.585^{* * *}$ & $-0.257^{* * *}$ & $-0.856^{* * *}$ \\
& $(-9.23)$ & $(-5.08)$ & $(-15.63)$ \\
\hline Ld & $-1.779^{* * *}$ & $-1.206^{* * *}$ & $-2.864 * * *$ \\
\hline
\end{tabular}




\begin{tabular}{|c|c|c|c|}
\hline & $(-22.62)$ & $(-21.67)$ & $(-9.75)$ \\
\hline MP & $\begin{array}{c}0.142 * * * \\
(18.40)\end{array}$ & $\begin{array}{c}0.096^{* * *} \\
(15.57)\end{array}$ & $\begin{array}{c}0.189^{* * *} \\
(9.11)\end{array}$ \\
\hline MP*Ld & $\begin{array}{c}-1.131 * * * \\
(-19.41)\end{array}$ & $\begin{array}{c}-0.879 * * * \\
(-16.32)\end{array}$ & $\begin{array}{c}-1.812 * * * \\
(-9.21)\end{array}$ \\
\hline Cashflow & $\begin{array}{c}0.032 * * * \\
(4.14)\end{array}$ & $\begin{array}{c}0.122 * * * \\
(4.73)\end{array}$ & $\begin{array}{l}-0.089 \\
(-1.30)\end{array}$ \\
\hline TobinQ & $\begin{array}{l}0.004 \\
(1.28)\end{array}$ & $\begin{array}{l}0.005^{*} \\
(1.690\end{array}$ & $\begin{array}{l}0.004 \\
(0.69)\end{array}$ \\
\hline Nwc & $\begin{array}{c}-0.077 * * * \\
(-4.62) \\
\end{array}$ & $\begin{array}{c}0.052 * * * \\
(3.25) \\
\end{array}$ & $\begin{array}{c}-0.173 * * * \\
(-4.20) \\
\end{array}$ \\
\hline Size & $\begin{array}{c}0.046^{* * *} \\
(14.74)\end{array}$ & $\begin{array}{c}0.026 * * * \\
(10.81)\end{array}$ & $\begin{array}{c}0.089 * * * \\
(8.19)\end{array}$ \\
\hline Lev & $\begin{array}{c}-0.062 * * * \\
(-3.88)\end{array}$ & $\begin{array}{l}-0.009 \\
(-0.56) \\
\end{array}$ & $\begin{array}{c}-0.089 * * \\
(-2.25)\end{array}$ \\
\hline Capex & $\begin{array}{c}-0.537 * * * \\
(-8.38)\end{array}$ & $\begin{array}{c}-0.380 * * * \\
(-7.03)\end{array}$ & $\begin{array}{c}-0.789 * * * \\
(-4.47)\end{array}$ \\
\hline Dividend & $\begin{array}{c}0.039 * * * \\
(7.34)\end{array}$ & $\begin{array}{c}0.031 * * * \\
(6.64)\end{array}$ & $\begin{array}{c}0.062 * * * \\
(4.39)\end{array}$ \\
\hline First & $\begin{array}{c}-0.028^{*} \\
(-1.79)\end{array}$ & $\begin{array}{c}-0.030 * * \\
(-2.22)\end{array}$ & $\begin{array}{c}0.076^{*} \\
(1.85)\end{array}$ \\
\hline Industry & Yes & Yes & Yes \\
\hline Observations & 11690 & 7532 & 4158 \\
\hline P-value & 0.0000 & 0.0000 & 0.0000 \\
\hline
\end{tabular}

Cashholdings is (cash and cash equivalents)/total assets, Ld is long-term debt (more than one year)/total debt, MP is monetary policy tightening annual dummy variable, 2004, 2006, 2007, 2010 and 2011 are defined as the monetary policy tightening year, $\mathrm{MP}=1$; the other years $\mathrm{MP}=0, \mathrm{Nwc}$ is net operating activity cash flow/total assets of the company, TobinQ is market value of total assets / book value of total assets, Roe is net profit / shareholder equity balance, Size is natural logarithm of total assets, Lev is total liabilities / total assets, Capex is capital expenditure / total assets, First is the shareholding ratio of the largest shareholder, Am is fixed assets / total assets, Taxraterate is income tax expense / pre-tax accounting profit, Industry is Industry dummy variable used to control the impact of industry factors

Note: The value in parentheses is the value of $\mathrm{t}$; * indicates that the result is significant at the $10 \%$ level, ** indicates that the result is significant at the $5 \%$ level, and *** indicates that the result is significant at the $1 \%$ level.

\subsection{Further analysis: the nature of the owner}

The literature has shown that in the allocation of credit resources, China's private enterprises face relatively serious credit discrimination, so companies with different owners may have different cash holding decisions. Compared with private enterprises, state-owned enterprises can get more government support in finance and politics. Moreover, in China's credit market, state-owned banks have a major share, and there is a natural interest relationship between state-owned enterprises and state-owned banks. State-owned enterprises can naturally receive more funds from state-owned banks. Therefore, compared with state-owned enterprises, non-state-owned enterprises are subject to strong financing constraints, so that monetary policy, debt maturity and other factors have a greater impact on cash holdings. Based on this, the paper further divides the sample into two sub-samples of state-owned and non-state-owned. Columns (2) and (3) of Table (3) are regression results. From the estimation results in Table(2): First, the debt maturity variable (Ld) is significantly negative both in state-owned enterprises and non-state-owned enterprises, and the estimated coefficient in the sample of state-owned enterprises is -1.606 , in non-state-owned enterprises. The middle is -2.864 , which indicates that the debt maturity (default risk) has a greater impact on the cash decisions of non-state enterprises. Second, under the tightening monetary policy, both state-owned enterprises and non-state-owned enterprises will increase cash holdings, but the tightening monetary policy will have a greater impact on non-state-owned enterprises. Finally, the interaction between monetary policy and debt maturity $(\mathrm{MP} * \mathrm{Ld})$ is -0.879 in the sample of state-owned enterprises and -1.812 in 
non-state-owned enterprises, both of which are significantly negative. In summary, the analysis shows that there is a difference in ownership between the monetary policy and the debt maturity impact on the company's cash holdings.

\subsection{Robustness test}

In order to make the results of this paper more reliable, we conducted the following robustness test: 1 . Use "cash and cash equivalents/(total assets - cash and cash equivalents)" to measure cash holdings; 2. use "long-term borrowings (More than a year) / (long-term borrowing + short-term borrowing)" measures the debt maturity structure; 3 . The research sample of this paper is panel data, so we use the fixed effect model (FE) and random effect model of panel data for table 2 ( RE) to estimate simultaneous equations (1) and (2). The results of these robustness tests are basically consistent with the previous ones, indicating that the main research conclusions of this paper have not changed substantially.

\section{Research conclusions}

This paper uses the data of Chinese listed companies from 2001 to 2015, and uses the debt maturity structure as the entry point to study the impact of refinancing risks on corporate cash holdings. The study found that: First, the possibility of the company's cash holdings and the debt maturity are determined endogenously, and the debt maturity structure is significantly negatively correlated with the company's cash holdings. That is to say, the more short-term debts of the company, the greater the cash holdings. This means that the company is able to mitigate the risk of refinancing due to short-term debt through more cash holdings. Second, the company's cash holding decisions are significantly affected by monetary policy. When monetary policy is tightened, listed companies will be cautiously motivated and increase the cash holdings; third, the longer the company's debt maturity, the lower the refinancing risk, the less the cash holdings of listed companies with longer debt maturity during the monetary policy tightening period; and finally, compared with state-owned enterprises, the cash holdings of state-owned enterprises are more affected by the debt maturity structure and monetary policy.

The conclusions of this paper have certain implications for the government and enterprises. On the one hand, it has reference significance for the management of enterprises. The most flexible part of corporate assets is cash, and the company's cash management has an important impact on the overall flexibility of the company. The results of this paper indicate that companies should consider the impact of default risk and monetary policy in cash holding management, so as to better manage the cash holding adjustment process and improve performance. On the other hand, it has reference significance for the government to formulate policies. The results of this paper show that the cash holdings of enterprises are affected by monetary policy. The impact of monetary policy on cash holdings of different ownership enterprises is significantly different. Macroeconomic policy makers should pay attention to such differences in considering the consequences of policy and economics, and deepen the reform of state-owned enterprises. We will rationalize the relationship between banks and enterprises and ensure the efficiency of credit resources.

\section{Acknowledgement}

This research was financially supported by Jiangsu University Philosophy and Social Science Fund Project (Grant NO2018SJA0251).

\section{References}

[1] Denis, D. J. and Sibikov, V, Financial Constraints, Investment, and the Value of Cash Holdings, Review of Financial Studies, vol.23, pp. 247-269, 2010. 
[2] Duchin, R., Ozbas, O. and Sensoy, B, Costly External Finance, Corporate Investment, and the Subprime Mortgage Credit Crisis, Journal of Financial Economics, vol. 97, pp.418-435, 2010.

[3] Qiu, J. and Wan, C, Technology spillovers and corporate cash holdings, Journal of Financial Economics, vol. 115, pp.558-573, 2015.

[4] Faulkender, Michael and Mitchell A. Petersen, Does the source of capital affect capital structure? Review of Financial Studies, vol 19, pp.45-79, 2006.

[5] Roberts, Michael R and Amir Sufi, Renegotiation of financial contracts: Evidence from private credit agreements, Journal of Financial Economics ,vol.93, pp.159-184, 2009.

[6] Zhang Huili and $\mathrm{Wu}$ Youhong, Excess cash holding level and product market competitive advantage, Journal of Financial research, vol.2, pp.183-195, 2012.

[7] Rao Pingui and Jiang Guohua, Monetary Policy, Credit Resource Allocation and Corporate Performance, Journal of Management World, vol.3, pp. 12-22, 2013.

[8] Xiao Ming et al, Research on cash holdings of listed companies in China based on macroeconomic perspective, Journal of China Management Science, vol.3, pp.28-34, 2013.

[9] Cai Weixing, Zeng Cheng and Hu Zhiying, Corporate Group, Monetary Policy and Cash Holding, Journal of Financial Research, vol.2, pp.114-130, 2015.

[10] Opler, Tim, Lee Pinkowitz, Ren'e Stulz and Rohan Williamson, The determinants and implications of corporate cash holdings, Journal of Financial Economics, vol.52, pp.3-46, 1999. 